\title{
EFFECTS OF SERVICE QUALITY, CUSTOMER TRUST AND CUSTOMER RELIGIOUS COMMITMENT ON CUSTOMER SATISFACTION AND LOYALTY OF ISLAMIC BANKS IN EAST JAVA
}

\author{
Rachmad Hidayat, Sabarudin Akhmad, Machmud ${ }^{1}$
}

\begin{abstract}
Effects of Service Quality, Customer Trust and Customer Religious Commitment on Customers Satisfaction and Loyalty of Islamic Banks in East Java. The purpose of the present study was to describe the relationships among service quality, customer trust and customer religious commitment on customer satisfaction and loyalty of Islamic banks in East Java. Respondents were Islamic banks' customers domiciled in East Java. A predetermined number of samples were taken by the use of a simple random sampling technique. Analysis was performed using the Structural Equation Modeling (SEM). Results indicated that service quality and customer trust of Islamic banks jointly had significant effects on customer satisfaction. Service quality and customer trust had direct and indirect effects on customer loyalty mediated by satisfaction of Islamic banks' customer in East Java. Religious commitment had no direct and indirect effect on customer satisfaction and customer loyalty.
\end{abstract}

Keywords: Service quality, trust, religious commitment, satisfaction and loyalty

Abstrak: Pengarub Kualitas Layanan, Kepercayaan dan Komitmen Beragama Nasabab Terhadap Kepuasan dan Loyalitas Nasabah BankBank Syariab di Jawa Timur. Penelitian ini menjelaskan hubungan antara kualitas layanan, kepercayaan nasabah dan komitmen beragama terhadap kepuasan dan loyalitas nasabah Bank-bank Syariah di Jawa Timur. Responden adalah nasabah Bank Syariah yang berdomisili di Jawa Timur. Penarikan sampel penelitian dilakukan dengan cara sampling acak sederhana, dengan jumlah yang telah ditentukan. Analisis yang digunakan pada penelitian ini adalah model persamaan struktural (Structural Equation Modeling atau SEM). Hasil penelitian ini menunjukkan bahwa kualitas layanan dan kepercayaan nasabah bank syariah secara bersama-sama berpengaruh signifikan terhadap kepuasan nasabah. Kualitas layanan dan kepercayaan nasabah berpengaruh terhadap loyalitas nasabah, baik langsung maupun tidak langsung dengan dimediasi oleh kepuasan nasabah bank syariah di Jawa Timur. Sedangkan komitmen beragama tidak berpengaruh terhadap kepuasan nasabah dan loyalitas nasabah baik langsung maupun tidak langsung.

Kata kunci: kualitas layanan, kepercayaan, komitmen beragama, kepuasan dan loyalitas

First draft: January, 20 $0^{\text {th }} 2015$, Revision: March, 07 ${ }^{\text {th }} 2015$, Accepted: March, $28^{\text {th }} 2015$

${ }^{1}$ Department of Industrial Engineering, University of Trunojoyo, Department of Islamic Education, STI Al-Karimiyah

Email:rachmad_h@ymail.com,drs.mahmud.mpdi@gmail.com, sabarutm@gmail.com 


\section{Introduction}

Islamic banking in Indonesia is growing in an exceedingly rapid pace. It is no longer a mere fulfillment of sharia obligation but has become a necessity. The proportion of Islamic banking for the next 10 years is expected to reach $15 \%-20 \%$ of the national banking system. In order to maintain the momentum of rapid-growing Islamic finance industry in Indonesia, various parties have been conducting several things, such as education and capacity building for Islamic finance industry and encouraging innovations in Islamic financial products to deepen the market and improve public access to Islamic financial institutions. Sharia financial industry, in particular Islamic banks, will continue to evolve with the growth of Muslim middle-class community. In addition to guaranteeing bank customer deposits, the Deposit Guaranty Institution (known as Lembaga Penjamin Simpanan or LPS) actively participates in maintaining financial stability embodied in the rescue of banks, the source of which is not the state budget, but premiums from banks. At present, there is a difference between Islamic banks and conventional banks with regard to deposit guaranty, in which the stipulation of LPS interest rate does not apply to the former. The implementation of LPS duties and functions is expected to reassure the customers of Islamic banks and consequentially facilitate the operations of Islamic banks.

Islamic banks operate in accordance with the principles of Sharia, in which they are not burdened with paying interest for customer deposits. Islamic banks only pay a share of profits in accordance with the profit-sharing ratios of Islamic banking. With the profit-sharing system, Islamic banks certainly survived the negative spread. Rather than collapsed as with the conventional banks in general, the past economic and financial crisis, instead, had positive impacts on the development of Islamic banks. Until 2007, there were 3 commercial Islamic banks, 24 Islamic business units and 105 Islamic People's Credit Banks (known as BPRS or Bank Perkreditan Rakyat Syariah). Islam, as a universal and integral teaching, regulates all aspects of human life, such as the social, cultural, political, legal, defense and security as well as economic and financial aspects. Along with the development of Islamic valueswithin the society after the collapse of Soviet communism in the 1990s, Samuel Paul Hantington stated that the threat to Western world is Islamic civilization (Qardhawi, 2001). The ultimate purposes of Sharia are to bring about virtues and to prevent damage. Sharia sets five basic human needs that must be protected by law: religion, life, property, reason, and offspring. It is in this respect that Allah makes the teachings of the Prophet Muhammad rahmatan lil alamiin (or blessings to all).(Q.S. Al-Anbiya [21] : 107). 
In the Islamic economic system, the interest rate paid by banks to depositors is replaced by a percentage or portion of profit sharing and the interest rate received by the banks (from debtors) is replaced by a percentage of profit sharing. These two forms of the ratio of profits are used as the instrument to mobilize savings and to channel it to productive business activities. Moslem economists emphasize that there is a built-in power of the Islamic economic system to ensure stability. Therefore, they argue that in the profit-sharing mechanism there will be no factor that leads to economic instability. In his analysis of the profit-sharing behavior with regard to economic stability, Nejatullah Siddiqi comments that: "the introduction of ratios of profit sharing to replace rate of interest will not destabilize the economy and that the change in the entrepreneurial profit will not get communicated back all along the line" (Muhammad, 2001). An economic system based on profit sharing shall better ensure allocation of economic resources and more proper distribution of income. The role of profit sharing in the achievement of economic stability should be analyzed by the use of an equilibrium approach.

Islamic banking has been providing superior products that conform to the Sharia. However, there are still many customers who are in doubt of its professionalism and service quality. Superiority in products remains in sufficient for customer satisfaction and loyalty. Banking customers are increasingly critical that the products and services provided affect banks' survival (Rahman, 2004). Superior service quality will affect customer satisfaction (Babin, et.al, 2005). Consequently, high customer satisfaction translates to higher profits for banks. Another advantage is an increased customer loyalty (Chan, et.al. 2003; Ruyter and Bloemer, 1999; Chan, et.al, 2004).There are a lot of criticisms associated with service quality of Islamic banks, especially regarding the application of the profit-sharing system. Some complained front-office service that seemed less professional. This situation should be resolved to maintain loyalty of customers who are motivated by sharia to use Islamic banks. Among the efforts to address this problem is to improve service quality of Islamic banks that involve product conformity with Islamic principles that differentiate Islamic banks from conventional banks.

\section{Literature Review}

In the context of banking service quality, service quality is a relatively special or superior service delivery to the customer's expectations (Cronin \& Taylor, 1992). There are two factors that affect service quality: expected services and received services. Service quality is the extent to which reality and customers' expectations differ with regard to the services they perceive (Parasurama, 1996). 
Service quality is the outcome of consumers' current evaluation and consumption experience and is expected to have a direct and positive effect on overall customer satisfaction (Parasuraman, 1996). Service quality is the level of satisfaction created by a particular transaction between the bank and the customer, which is a psychological condition generated when emotional factors encourage expectations and adapt to past consumption experience (Oliver, 1981).

Satisfying customers for a company engaged in banking services is a key point that should not be overlooked, where customer satisfaction is a strategic aspect to win the competition and maintain the company's image within the broader communities; thus, quality services to customers are of ultimate importance. Entering the competition on a global scale, Islamic banks are challenged to contribute to the national development through economic empowerment of the people. Service quality is a form of consumers' evaluation of the level of perceived services and the level of expected service. Improving service quality constitutes a realistic way for a bank to win the competition and retain customers. Hence, customer satisfaction in the service sector is an important and decisive element to develop the company in order for survival in the face of competition.

This implies that there is a difference when service quality is seen as an attitude since satisfaction is different from attitude. Customer's attitude to a product or service is relative, while satisfaction is an emotional reaction to past consumption experience. In line with the difference, service quality can also be distinguished by the level of satisfaction since perception of service quality is a result of thorough consideration or attitude in response to the excellence of a service, while the level of satisfaction relates only to a particular transaction in a relatively short period.

Trust is the belief that the action of another person or a group is consistent with their beliefs. Trust is created through a gradual and subsequently accumulated process (Pradiansyah, 1999). Consumer trust can be explained through dimensions of past experiences, information and enthusiasm. Consumer trust depends on the consumer's experience with consuming goods or services and receiving favorable information from the service provider. Thus, experience and favorable information will foster consumer trust in a product or service. This is because the experiences stored in the memory of the consumer for a product or service are capable of establishing a person's trust if the those experiences are enjoyable and satisfy them. Consumer trust will be exhibited by their response to the information delivered by the service provider. Consumer enthusiasm or attachment is their positive response to a product or service they receive.

Commitment is the motivation and engagement as well as performance and 
adherence to an organization (Gunlach, 1995). Religion provides the best that human beings need to determine the purposes of their lives. Religion promises happiness and prosperity, morality, work ethics, management of justice and what human beings need in their association with their fellow human beings and all the elements of nature (Achsien, 2000). Thus, religious commitment is a form of adherence to religious teachings. To Muslims, Islam is a way of life that sets the whole aspects of life, in line with the order "O you, who have believed, enter into Islam completely........" (Q.S. Al Baqarah [2] : 208).

Analysis of the relationship of religion and commitment with ethics does not end in religious affiliation. It is continued with religious commitment to reach religiosity. Dimensions used to measure religious commitment are: first, visits to the place of worship; second, participation in religious activities; and third, the level of personal religious faith. The levels of religious faith are captured by four items: first, belief in God; second, belief after death; third, agreement with the idea that one has the right to question what his church teaches and fourth, agreement with the idea that one has the right of free speech includes the right to make speeches criticizing religion (Taufik \& Karim, 1989). The relationship between the customer and the bank is more than a simple functional relationship; rather, it is exceptionally emotional and the tie can be very strong (Shemwel, 1998).

Generally, banks want their customers can be retained for good. Accordingly, in the context of banking services, customer loyalty is customer commitment to a bank based on a very positive attitude and is reflected in the consistent repeat purchases (Fandi). Repeat purchase may be the result of market dominance by a bank successfully making its products the only products available. Consequently, customers do not any other option to look for other products. Besides, it can repeat purchase may be the results of continuous promotion in order to entice and lure customers to use a product. In case of no market dominance and intensive promotion efforts, only the loyal customers are committed to repeat purchase. Loyalty will be established by the habits and the long history of banking product consumption. Customer loyalty is affected by continuously accumulated satisfaction or dissatisfaction in addition to the perceived quality of a product (Boulding, et.al, 1993).

Banks capable of satisfying their customers in the long run make their customers loyal and making repeat purchases. Additionally, perceived agreement of a bank's performance is influenced by service quality of the bank concerned. If the bank is capable of providing service quality in accordance with customer expectations, the customer will be satisfied with the services provided by the bank. The more the quality of services provided by bank the more satisfied the 
customer will be. The better the service quality provided by the bank the more loyal the customer to the bank will be. This is in line with studies of Cronin dan Taylor (1992), Zeithaml and Bitner (1996), Bloemer, et.al (1998), Lassar et al.(2000), Natalisa (2000), Holm (2000), Bei dan Chian (2001), Astuti (2001), Kadir (2001), Fullerton dan Taylor (2002), Caruana (2002), Said (2004) that concluded that service quality has significant direct and indirect effects on customer loyalty mediated by customer satisfaction.

Islamic banks can be used for cash management, i.e. management of all the financial traffics of a company. Therefore, customers will partner with only one Islamic bank, making them more easily, efficiently and uncomplicatedly managing their finances. Customers partnering with many banks may have inconvenience in managing their finances. One condition that needs to be considered in choosing which Islamic banks to be used for cash management is that the bank is capable of serving various types of transaction that the company needs. Trust and credibility constitute the main prerequisites for the bank to be chosen by customers in partnering or transacting.

Trust is to believe in a partner to a relationship due to the partner's credibility and benevolence. Credibility indicates trust gained from others due to having the desired expertise to perform a task. Additionally, trust is gained due to having good manners to other partners to a relationship. Trust arises from the ability to prove something, from reliability and from intentionality. Trust is the desire of one party to be well-treated by the other party in the hope that the other party will take necessary actions to meet the expectation, regardless of the ability to monitor or control the other party (Mayer, et.al, 1995). The components of trust are credibility, reliability and intimacy (Peppers and Roger, 1996). Commitment is the desire to maintain connectivity in the long run.

Loyalty is a behavioral response that is biased or non-random, continuously revealed by decision makers by paying attention to one or more alternative products and a number of similar products and is a function of psychological processes (Dharmesta, 1999). In contrast to repeat purchase, customer loyalty involves customer's repeated psychological feelings towards products and services for a long period of time. Loyalty will occur based on the experience with consuming a number of similar products. This experience will affect the final decision making where customers decide to be loyal to only one banking products. Bank customers have a religious commitment reflected in the customers' consumption attitudes and behaviors. This attitude is measured by way of asking the customers how they like the products offered, how strong their religious commitment to Islamic banks and their tendency to recommend the bank to others as well as 
their beliefs and feelings to banking products.

Commitment is a determinant of the success of a long-term relationship between the consumer and the service provider (Hazra and Kailash, 2009). Customer commitments play a key role in the success of a long-term relationship between service providers and customers, which in turn will create customer loyalty (Ramadania, 2002). Commitment is closely connected with customer loyalty, which is intention to making a purchase and intensive repeat purchases. Repeat-purchase behavior can be described in two possibilities, loyalty and inertia (Odin, et.al, 2001). Repeat-purchase behavior in a situation of strong brand sensitivity is categorized as loyalty. Conversely, repeat-purchase behavior in a situation of weak brand sensitivity is categorized as inertia. Loyalty is long-term and cumulative (continuous) in nature; the longer the customers to be loyal, the more the profit the bank can obtainfrom the customer's banking transactions. Customers categorized as loyal are those customers who are so satisfied with a specific banking product that they are enthusiastic to introduce it to anyone they know (Tjiptono, 2004). Furthermore, customers will make repeat purchases of banking products they usually buy; even these customers will not use other banking products. The bank's strengths and weaknesses will be informed to the bank and even the customer will inform the bank's strengths to others.

Customer satisfaction is the level of customer feelings after comparing their perceived performance of a product or service to their expectations. Satisfaction arises when customers compare their perceived performance of a product or service to their expectations (Spreng, et.al, 1996). Thus, customer satisfaction is formed after the perception of the value of an offer. Or, in other words, the level of customer satisfaction is a function of the difference between the perceived performance and expectations. Customer satisfaction occurs when the results of evaluation of the banking products used are at least equal to or exceed customer expectations, while dissatisfaction occurs when the results of evaluation do not meet or are below customer expectations.

Most customers like banking products after using them. Repeat consumption leads to customer loyalty. Loyalty is seen as a final effect of repeat purchases made by consumers (Caruana, 2002). Repeat purchase may be due to lack of compatibility after repeated use of banking products or customers are conditioned to use one only banking products. The final effect arising from these conditions is customers that will be loyal to an improved product by repeated consumption in the long term. Loyalty can be as developing in three phases: cognitive, affective and conative. 


\section{Methods}

Population in this study is all the customers of Islamic banks in East Java. Samples were representatives of the population studied (Arikunto, 2010). that were taken by the use the simple random sampling technique. A predetermined number of samples were randomly selected only in 3 major cities in East Java - Surabaya, Sidoarjo and Malang. The number of samples in this study was 150 respondents according to the sample size guideline of 100-200 (Arikunto, 2010). Fifty respondents were taken from each city.

Samples were Islamic bank's customers domiciled in East Java. East Java Province would be developed to be the largest Islamic economic region in Indonesia. Another reason was that East Java Province had the potential for the development of Islamic economy with the support of 6,000 Islamic boarding schools (known as pondok pesantren). The management of Islamic boarding schools also asked the government to maximize the program. All Muslim clerics (known as kiai) in East Java have been supporting the concept of Islamic economic restructuring. The institution of Islamic boarding school, known as one of the means of Islamic preaching, could be optimized to drive Islamic financial education in Indonesia.

Figure 1. The Structural Model

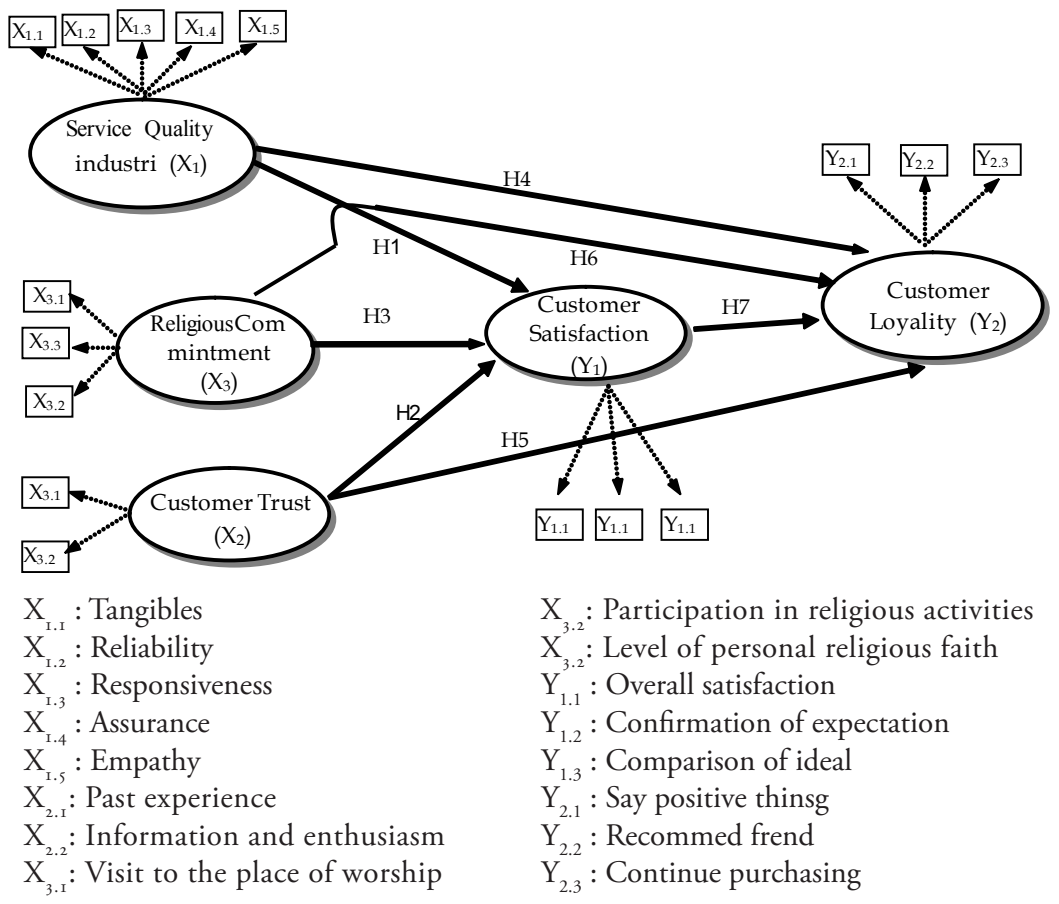


Hypotheses proposed in this study were:

H1: Service quality of Islamic banks had significant effects on customer satisfaction of Islamic banks in East Java;

H2: Customer trust of Islamic banks had significant effects on customer satisfaction of Islamic banks in East Java;

H3: Religious commitment of Islamic banks' customers had significant effects on customer satisfaction of Islamic banks in East Java;

H4: Services quality of Islamic banks had significant effects on customer loyalty of Islamic banks in East Java;

H5: Customer trust of Islamic banks had significant effects on customer loyalty of Islamic banks in East Java;

H6: Religious commitment of customers of Islamic banks had significant effects on customer loyalty of Islamic banks in East Java;

H7: Customer satisfaction of Islamic banks had significant effects on customer loyalty of Islamic banks in East Java.

Structural Equation Modeling (SEM) analysis was used to test the hypotheses. In order to test the goodness of fit of the model developed in the structural equation modeling, the fit index was used. If the model was not quite good, it is necessary to modify the model by adding or deleting the links so that the value of chi-square will decrease with the value of the index (Ferdinant, 2000).

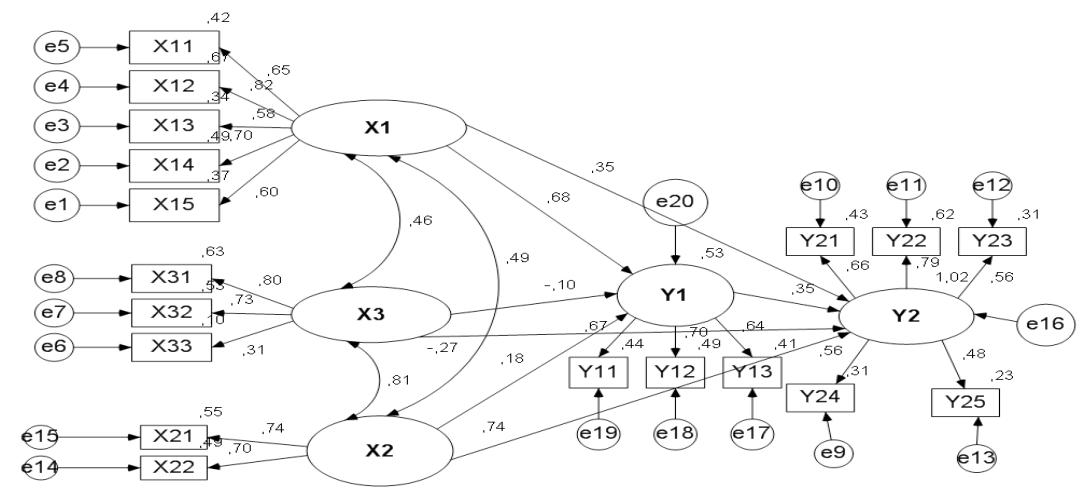

Figure 2. The Result of Structural Model

\section{Discussion}

Hypotheses of the study were tested by partially examining each path of direct effects based on the results of the Structural Equation Modeling (SEM) analysis. Indirect effectswere the byproducts of direct effects. Hypotheses of direct effect were tested based on the value of $\mathrm{CR}>1.96$ and $P<0.05$, meaning a 
significant effect. Results of hypothesis testing are as follows.

\begin{tabular}{llcc}
\hline \multirow{2}{*}{ Independent Variable } & Dependent Variable & \multicolumn{2}{c}{ Direct Effect Path } \\
\cline { 3 - 4 } & & $\begin{array}{c}\text { Coefficient } \\
\text { Std }\end{array}$ & Note \\
\hline Service quality & Customer satisfaction & 0,68 & Significant \\
Customer trust & Customer satisfaction & 0,18 & $\begin{array}{c}\text { Significant } \\
\text { Non }\end{array}$ \\
Religious commitment & Customer satisfaction & $-0,10$ & Significant \\
Service quality & Customer loyalty & 0,35 & Significant \\
Customer trust & Customer loyalty & 0,74 & Significant \\
Religious commitment & Customer loyalty & 0,64 & Significant \\
Customer satisfaction & Customer loyalty & 0,35 & Significant \\
\hline
\end{tabular}

After testing and analyzing the effects of service quality, customer trust and customer religious commitment on customer satisfaction and customer loyalty of Islamic banks in East Java, and after reviewing theoretical concepts and empirical supports regarding the causal relationship between the variables affecting customer loyalty of Islamic banks, the theoretical and empirical findings leading to the development of the theory generated in this study are: First, service quality and customer trust had effects on customer satisfaction of Islamic banks. Results showed that service quality was instrumental in creating customer satisfaction, while customer satisfaction was the dominant variable in building customer loyalty. Efforts to retain customers of Islamic banks will be realized by taking into account service quality and customer satisfaction in addition to the trust variable. Customer satisfaction was to be achieved by improving service quality provided to customers.

Superior service quality can be created by providing appropriate training to all employees on how to serve customers in accordance with their expectations. Training is provided not only to the division in charge of service encounter, but all parties should be involved in the training on service quality. Involvement of all parties will lead to excellent service quality so that the image of Islamic banks will be getting better in the eyes of customers. There is a need for evaluating the extent of customer loyalty of Islamic banks. Evaluation should be done on a regular basis so that the bank will always able to identify customer needs and respond them quickly. Customer loyalty can also be enhanced by placing an emphasis on the intimate relationship with customers. Programs long remembered in minds of customers will be able to strengthen the relationship with the customers, for example through Islamic banks' involvement in religious activities. 
Second, in addition to service quality, customer satisfaction and loyalty of Islamic banks are also influenced by customer trust. Customer trust is an important element affecting the quality of a relationship. Customer trust in the Islamic banks will increase the levels of customer satisfaction with Islamic banks. Customer satisfaction will increase the likelihood that the customers make repeated consumption. The high level of trust will have an effect of reducing the possibility of customer shift to non-Islamic banks. One effort that should be carried out by the management of Islamic banks to increase customer trust in order to enhance customer satisfaction as the predictor of customer loyalty of Islamic banks is to build the capacity of bank employees in serving customers. Customer trust can also be built from the attitudes of Islamic banks' employees that promote honesty and do not take short-term advantage. Long standing relationship with customers can be well-maintained.

Third, not all study variables had significant effects on service quality. Religious commitment was shown to have no effect on customer satisfaction and customer loyalty of Islamic banks. This was due to the fact that customers of Islamic banks derived from a limited number of Muslims in East Java. Additionally, the variable religious commitment was customer personal commitment to practicing Islamic teachings. Customer religious commitment had no direct effect on service quality, but customers with their beliefs in the functions and benefits of Islamic banks straightly expressed their loyalty to Islamic banks. Customers chose and were loyal to Islamic banks based on their religious faith and obligations to apply Sharia in their everyday lives. Thus, any form of service provided did not have significant effect on customer satisfaction. Customers expressed their high loyalty to Islamic banks regardless their satisfaction as reflected by service quality of Islamic banking.

In addition to the underlying personal factors, negative relationship between religious commitment and customer satisfaction was also due to the limitations of the study. Negative effects on customer satisfaction and customer loyalty might be due to the fact that not all indicators of the variable religious commitment were able to explain comprehensively the relationships between customer satisfaction and customer loyalty. Another factor was that the short period of the study, leading to fairly limited number of observations. The study location also influenced the effects of this relationship. East Java was chosen as the study location since the province was considered as capable of implementing the program to accelerate the development of Islamic economics. Besides, as stated in the vision of Islamic economic development in Indonesia, East Java Province is to be developed as the largest Islamic economic region in Indonesia. East Java also 
has the potential for the development of Islamic economics in East Java, which is supported by 6,000 Islamic boarding schools. The management of Islamic boarding schools also asked the government to maximize the program. All kiai in East Java have been supporting the concept of Islamic economic restructuring. The institution of Islamic boarding school, known as one of the means of Islamic preaching, could be optimized to drive Islamic financial education in Indonesia. With Islamic banking restructuring, the economic concept can be realized with low-cost, simple, and blessed financing.

\section{Conclusion}

Results showed that service quality and customer trust of Islamic banks were predictors of customer satisfaction and customer loyalty of Islamic banks. Customer satisfaction of Islamic banks was the intervening variable linking service quality and customer trust of Islamic banks to customer loyalty of Islamic banks. Customer religious commitment of Islamic banks had no direct effect on service quality of Islamic banks. This was due to the fact that customers of Islamic banks derived from a limited number of Muslims in East Java. The variable religious commitment was the customer personal commitment to practicing Islamic teachings. Results of the present study have theoretical and managerial implications. Managerial Implications recommend the banks to enhance customer loyalty by placing an emphasis on improving service quality. Future research should investigate a different object of study with regard to the form of business and location of the object of study. There is a need for considering addition of other variables which are continuation and antecedents of customer loyalty. Empirical research models should be examined from the viewpoint of service providers.

\section{References}

Achsien, I.H. 2000. Investasi Syariah di Pasar Modal. Jakarta: Gramedia Pustaka Utama.

Al-Qardawi, Yusuf. 2001. Umat Islam Menyongsong Abad Ke-21. Surakarta: Era Intermedia.

Arikunto, S. 2010. Prosedur Penelitian Suatu Pendekatan Praktek. Jakarta:Rineka Cipta..

Astuti, S.W. 2001. Dampak Pemasaran Jasa Rumah Sakit Terhadap Nilai, Kepuasan dan Loyalitas Pasien. Penelitian Pada Pasien Rawat Inap Rumah Sakit Umum di Tiga Ibu Kota Propinsi di Pulau Jawa. (Unpublished Disertation). Surabaya: Universitas Airlangga. 
Babin, B. J. et.al. 2005. Modeling consumer satisfaction and word-of-mouth: restaurant patronage in Korea. Journal of Services Marketing, Vol. 19 No. 3, 2005, pp. 80-95

Bei, L.T. \& Y.C. Chiao. 2001. An integrated model for the effects of perceived product, perceived service quality, and perceived price fairness on consumer satisfaction and loyalty. Journal of Consumer Satisfaction, Dissatisfaction and Complaining Behavior. Vol. 14, 2001, pp. 25-40

Beerli, A. et.al. 2004. A model of customer loyalty in the retail banking market. European Journal of Marketing, Vol. 38 No. 1/2, 2004, pp. 50-62

Bloemer, J. et.al. 1998. Investigating drivers of bank loyalty: the complex relationship between image, service quality and satisfaction. The International Journal of Bank Marketing. Vol. 16. pp. 276-292.

Boulding, W. et.al. 1993. A Dynamic Process Model of Service Quality: From Expectations to Behavior Intentions. Journal of Marketing Research. Vol. 30 (February). 1993, pp. 100-112

Caruana, A. 2002. Service Loyalty. The Effect of Service Quality and The Mediating Role of Customer Satisfaction. European Journal of Marketing. 36, pp. 10-22

Chan, L. K. et.al. 2003. Consumer satisfaction index: New practice and findings. European Journal of Marketing, Vol. 37 No. 5/6, pp. 36-50

Cronin, J. et.al. 1992. Measuring Service Quality: A Reexanination and Extention. Journal of Marketing. 46 .July. pp. 45-60

Dharmmesta, B.S. 1999. Loyalitas Pelanggan: Sebuah Kajian Konseptual Sebagai Panduan Bagi Peneliti. Jurnal Ekonomi dan Bisnis Indonesia. Universitas Gajah Mada. Vol. 14, pp. 50-64.

Donal, J.S. et.al. 1998. Customer Service Provider relationships : an empirical test of model of service quality, satisfaction and relationships oriented outcomes, International Journal of Service Industry management, Vol 9 (2), pp. 19-30.

Fečikova, I. 2004. Index method for measurement of customer satisfaction. The TQM Magazine, Vol. 16 No. 1.

Ferdinant, A. 2000. Struktural Equation Modeling (SEM) Dalam Penelitian Manajemen. Semarang: Universitas Diponegoro.

Fomell, C. et.al. 1996. The American Customer Satisfaction Index: Nature, Purpose and Findings. Journal of Marketing. 60. Oktober, pp. 34-50.

Fullerton, G. \& S. Taylor. 2002. Mediating, interactive and Non-Linear Effect in Service Quality and Satisfaction with Service Research. Journal of Marketing. 46, JuIy, pp. 60-74

Gregory, T.G. et.al. 1995. The Structure of Comitment in Exchange. Journal of Marketing, Vol 59 (Januari), pp. 14-22. 
Holm, M.G. 2000. Service Quality and Product Quality in Housing Refurbishment. The International Journal of Quality \& Reliability Management. Vol. 17, pp. 102-115.

Kadir, A.R. 2001. Pengaruh Komitmen Manajemen Bank Terhadap Tingkat Kepuasan Kerja Karyawan dan Tingkat Kepuasan Nasabah di Sulawesi Selatan. (Unpublished Disertation). Surabaya: Universitas Airlangga.

Lassar, W.M. et.al. 2000. Service Quality Perspectives and Satisfaction in Private Banking. The International Journal of Bank Marketing. Vol. 18, pp. 18-32.

Mayer, R.C. et.al. 1995. An integrative model of organizational trust. Academy of Management Review, 20, pp. 709-734.

Muhammad. 2001. Tehnik Perhitungan Bagi Hasil di Bank Syariah. Yogyakarta: UII Press.

Natalisa, D. 2000. Pengaruh Komitmen Manajemen Terhadap Kualitas Layanan Untuk Meningkatkan Kepuasan Pelanggan Maskapai Penerbangan Domistik Sudut Pandang Pelanggan dan Penyaji Jasa. (Unpublished Disertation). Surabaya: Universitas Airlangga.

Odin, Y., N. et.al. 2001. Conceptual and Operational Aspects of Brand Loyalty: An Empirical Investigation. Journal of Business Research. 53, pp. 115-130.

Parasuraman, A. 1996. The Behavioral Consequences of Service Quality. Journal of Marketing. 40, pp. 120-138.

Peppers, D. \& M. Roger. 1996. Managing Customer Relationship Marketing. European Journal of Marketing, Vol. 30, pp. 163-180.

Rahman, Z. 2004. Developing customer oriented service: a case study. Managing Service Quality, Vol. 14 No. 5, pp. 12-24.

Ruyter, K. \& J. Bloemer. 1999. Customer loyalty in extended service settings: The interaction between satisfaction, value attainment and positive mood. International Journal of Service Industry Management, Vol. 10 No. 3, pp. 112-124.

Said, S. 2004. Pengaruh Kemampuan Mengolah Informasi Terhadap Loyalitas Nasabah Bank Rakyat Indonesia (BRI) di Sulawesi Tenggara. (Unpublished Disertation). Surabaya: Universitas Airlangga.

Tjiptono, F. 2004. Pemasaran Jasa. Malang: Bayumedia.

Zeithaml, et.al. 1996. Services Marketing. New York: McGrawHill. 